\title{
ГУМАНИТАРНАЯ ГЕОГРАФИЯ
}

УДК: 911.3:821.161.1”1992/..."

\author{
А.И.Зырянов \\ ГЛОБУС, ПАРМА И ТОБОЛ \\ (о писателе Алексее Иванове как географе)
}

Пермский государственный национальный исследовательский университет, Пермь

Художественные и публицистические книги Алексея Иванова - произведения историкогеографические, где проявляется синтез географии и истории, чувствуется понимание ландшафтов и эпох. Топографичность, маршрутность и походность лежат в основе его многих сюжетов. Писатель видит географическую структуру, показывает территорию концентрированно. Писательские находки становятся и научными географическими достижениями. Роман «Географ глобус пропил», где автор «стягивает» горные географические феномены Урала в зону путешествия, является захватывающим художественным произведением о туристском походе. В книге «Сердце Пармы» Пермь Великая поновому раскрывается как явление географическое, большое внимание уделяется осознанию единства народов Прикамья. Произведение «Тобол. Много званых» впервые дает целостный взгляд на Зауралье как на единый регион, является одой географической карте и труду географа.

К л юч е в ы е сл ов а : писатель Алексей Викторович Иванов, «Географ глобус пропил», «Сердце Пармы», «Тобол. Много званых».

\section{A.I. Zyrianov \\ GLOBUS, PARMA AND TOBOL \\ (About the writer Alexei Ivanov as a geographer)}

\section{Perm State University, Perm}

Aleksey Ivanov's art and journalistic books are historical and geographical works, where the synthesis of geography and history is manifested, and the understanding of landscapes and eras is felt. Topography, routing and march are the basis of many of its subjects. The writer sees the geographical structure, he can show the territory in a concentrated manner. Writings are also scientific geographical achievements. In the novel "The Geographer Globe Drunk," the author "pulls" the mountain geographical phenomena of the Urals into the travel zone and creates the exciting artwork about the tourist campaign. In the book "The Heart of Parma" Perm the Great is revealed in a new way as a geographical phenomenon, the novel does much to realize the unity of the peoples and ethnic groops of the Kama region. The work "Tobol. Many called "for the first time gives a holistic view of the Trans-Urals as a single region, the book is an ode to the geographical map and the work of the geographer.

Ke yw ords: writer Alexey Ivanov, "Geographer globes drunk", "Heart of Parma", "Tobol. Many are called".

\section{doi 10.17072/2079-7877-2017-3-43-47}

Произведения Алексея Викторовича Иванова имеют широкую аудиторию, вызывают интерес научного мира. Попытаемся разобраться в творческом феномене писателя, оценить его работы не столько в литературном отношении, сколько с исследовательских географических позиций.

Работы Иванова привлекают внимание географов и историков, поскольку в его произведениях ощущается синтез географии и истории. Это творения человека с развитым чутьем пространства и времени, пониманием ландшафтов и эпох. «Пространственная матрица региона», «ландшафт как генокод территории» - его исследовательские находки и новые понятия. Историко-географические композиции Иванова дополняются мастерством слова и способностью к фантазии. Интуиция достраивает отсутствующие сведения в исторических сюжетах, что позволяет писателю 
переосмысливать, подавать для читателя интересно уральские территории и события. Рассмотрим три романа Иванова, основанные на географии и полезные для географов.

Книга «Географ глобус пропил» [3] интересная и необычная, с ней познакомилось множество самых разных читателей, в том числе и профессиональные географы. Художественный фильм, который вызвал новую волну интереса к роману, обусловил еще более противоречивые суждения. О чем же эта книга. Она о Перми и Пермском крае, о географе и географии, о преподавании и педагогике, о школьниках и школе, о походе и сплаве, о самовоспитании туристской группы и особенностях края. В ней рассказывается в основном о неприятных сторонах общества, семейных взаимоотношений, о кризисе хозяйства и территории. У пермского жителя, имея в виду обычного человека, после прочтения возникает чувство печали: вроде бы в наших краях могло быть все прекрасно, а идет наперекосяк, безрадостно. Отметим, что действие романа относится к 90 -м гг. XX в.

Пермяка книга притягивает многим. Во-первых, она про один из районов Перми, а именно Водники. Этот район, который находится на Каме, связан с судозаводом. Сейчас мы так мало говорим и пишем об этой реке, хотя наш город стоит на Каме, и это главное в его положении. Вовторых, книга - про электрички. С автомобилизацией пермяки почувствовали себя богаче, почти отринули этот транспорт, но с удовольствием вспоминают электрички, еще недавно полные туристов с их бесплатными и достойными песнями. В-третьих, книга про нашу величавую и удивительно гармоничную природу, про уральские реки, подходящие для сплава, интересные и опасные. Все это не отстраненный пространственный фон в книге, а особая ивановская техника. Книга резкая до неправдоподобности, особенно в школьной теме. Это тот случай, когда педагоги, «перебирая» свой опыт, находят схожесть с сюжетными событиями этого произведения лишь в отдельных случаях.

Неправильно требовать от писателя точности на местности, поскольку это не отчет о совершенном путешествии, автор «стягивает» горные географические феномены Среднего Урала в зону похода. Он показывает пространство концентрированно, формулирует территорию [3].

Топографическая точность действия романа в пределах города Перми настраивает читателя на абсолютную правдивость. Географию городской части сюжета книги можно легко проверить, ее знают жители города. Эта географическая правдивость настраивает читателя на реализм сюжета и на реальность описываемого похода со школьниками. Такой прием позволяет писателю показать мир Среднего Урала концентрированно, собрав наиболее интересные и показательные географические явления и объекты в маршрут похода, представить весенний Урал ярко и приключенчески. Автор выбирает обыкновенный вариант подъезда на маршрут и ставит героев в некоторые типичные для такого похода ситуации. Вымышленные географические названия редки, они вкраплены в реальную топонимику и «работают» на правдивость в отношении похода. Писатель так прокладывает нитку путешествия, чтобы оно было как можно ближе к действительности, и даже специалисты-походники, а их на Урале великое множество, поверили в это. Не будем говорить о всей читающей публике, которая, безусловно, посчитает маршрут романа очень возможным, реалистичным.

Писатель очень грамотно выстраивает нитку активной части маршрута. Она частично новая, по ней редко ходят. Группу подвозит случайный лесовоз, и водитель легко догадывается, что речь идет о сплаве по данной реке. Значит это не абсолютно новая и нехоженая река, а просто очень редко посещаемая. Автор вводит в романе элемент необычности в программе путешествия. Герои проспали свою станцию, изменили намеченный путь, попытались выйти на свой запланированный маршрут, пройдя малохоженую реку или ее участок. Этим Иванов советует читателям, чтобы они не искали реальный географический объект или точный отрезок маршрута, поскольку досконально книжный путь не повторить. Однако в романе фигурирует название реки Поныш - это одно из наиболее глухих и загадочных мест Пермского края, сюда нет даже лесовозного пути от предполагаемой железной дороги.

Группа отправляется сплавляться по реке Ледяной, которая, судя по всему, как Чусовая и Усьва, является популярной рекой среди пермских водников. Ледяная - река вымышленная, она вбирает в себя все типичное для рек Горнозаводского Урала. Показать на примере одной реки достоинства других рек не трудно, поскольку, по мнению опытных сплавщиков, все реки Урала, особенно рассматриваемого района, очень похожи. Ледяная - название близкое для пермяка. Наша гордость Кунгурская ледяная пещера. Название Ледяная ассоциируется даже с Пермским Севером, если вспомнить реку Студеную - также собирательный образ, созданный Маминым-Сибиряком («Зимовье на Студеной»). Ледяная, река типичная для этого района: с большим майским половодьем, с быстрым 
весенним течением и опасными «расческами», со скалистыми берегами, с заброшенными деревнями, с лесовозными дорогами, с еловыми и сосновыми лесами с березой и осиной на старых лесосеках.

Территория в этом произведении Иванова может быть оконтурена мысленно как восточная часть Пермского края, в районе Чусового, но выделяется она не четко, размыто. События происходят на горно-лесном Среднем Урале. Названия станций Комарихинская, Валежная, Боковая, Парма, Семичеловечья, Гороблагодатская одного железнодорожного куста, но разных его веток. Таким образом, даже путь подъезда на электричке к участку сплава, описанный в романе, точно не повторить. Походное действие романа разворачивается, судя по всему, в Горнозаводском районе, на восточной окраине Пермского края, где станции и остановки на пересекающей Уральские горы железной дороге выходят к известным сплавным рекам, откуда лесовозные дороги ведут к верховьям вздувающихся в половодье притоков.

К географии А.В.Иванов отнесся с уважением и тактом. Герой книги - не учитель географии, а специалист по другому профилю, взявшийся за преподавание этого предмета почти случайно, из-за обстоятельств, и к нему трудно предъявлять профессиональные претензии. Однако он, как и подобает географу, пытается рассказывать интересно, «вытянуть» школьников на производственную экскурсию, показать им что-то важное в своем районе и, наконец, сводить в трудный поход. При всей бедолажности «географа» глобус он все-таки не пропил.

Про туристский поход написать интересный роман очень трудно, особенно для таких читателей, кто сам ходил. Художественная литература знает не так много ярких примеров увлекательных произведений о путешествиях. К таким можно отнести произведения Жюля Верна, Джека Лондона, Владимира Обручева. Казалось бы, самодеятельным туризмом занимались в нашей стране миллионы людей и много написано, но, на сколько могу судить, «Географ...» - первое захватывающее художественное произведение о туристском походе.

Несмотря на то, что данная книга о повседневности и неприятностях, она очень сюжетна и постранично умна. Кому-то она будет дорога тонкой иронией, кому-то меткими фразами, а кому-то и своеобразным обращением к географии Пермского края. Да и в человеческих отношениях не все грустно. Как сказал мой сын-восьмиклассник: «... хотя книга написана на минорный лад, но все-таки какая-то в ней надежда есть».

Перейдем к другому произведению А. Иванова, действие в котором разворачивается в Перми Великой. В романе «Сердце Пармы» [4] читателю нравится многое: острый сюжет, нескучная творческая подача исторических событий, яркие краски жизни того времени. При этом автор географии отводит ключевую роль, поэтому посмотрим на книгу как на географическое произведение.

Роман по содержанию историко-географический. Художественно описываются события XV в., многие из которых легендарны. Дается характеристика ландшафтов, рек и лесов, гор и скал, уклада населения, городков и деревенек, народов, соседских взаимоотношений княжеств, различных государственно-племенных образований.

Отметим топографическую привязанность всего сюжета. В романе множество географических названий, абсолютно реальных. Районы действия: Северное Прикамье, бассейн Вычегды, таежное Зауралье, земли Пермь и Югра, рассматривается связь Пермских территорий с Москвой, Новгородом, Казанью, Вяткой. Описываются природа и климат, сезоны года, яркие фенологические события; много цвета, поскольку действия происходят в основном за пределами стен дома, под открытым небом.

Роман маршрутный, большая его часть отведена каким-либо перемещениям. Описываются все известные в то время пути по тропам, дорогам, рекам из Чердыни в другие территории (по Посьмаку и Кутиму в Сибирь, по Березовке и Вишерке на Печору, по Каме вниз и вверх). Географический каркас романа построен на наиболее привлекательных в настоящее время природных объектах, районах и исторических пунктах (Полюд, Ветлан, Басеги, Кваркуш, Искор, Покча, Гайны, Кайгородок, Хохловка). Это позволяет говорить о знании автором глухих далеких и прекрасных пермских мест (Цепельские поляны).

Роман призывает к осознанию единства народов Прикамья. Каждые народы интересно, содержательно и глубоко раскрыты. Основные герои - представители разных народов Перми помогают друг другу, как говорится, стоят «плечом к плечу». Это русский Калина, коми-пермяк Полюд, татарин Иснур, коми-зырянин Зырян и, наконец, князь Михаил русско-вогульской крови персонажи достойные уважения и восхищения. 
Глава территории предстает человеком умным и мягким, интеллигентным и добрым, в роду которого есть и русский, и манси. Именно такой и нужен здесь: народы в Прикамье к друг другу изначально добры и не враждебны. Он - лидер и соединяет людей Перми Великой ценой московского раздражения и жестокого наказания, но в результате получает сплоченный народ, способный отразить внешнюю агрессию.

Роман о Перми Великой - это книга о пространстве и времени, о центростремительном и сбалансированном Пермском регионе со своей внутренней цементирующей силой. Алексей Иванов показывает Пермь Великую прежде всего как географический феномен [2].

Название романа «Тобол. Много званых» [5] начинается с географического имени места, с наименования реки, хотя и не малоизвестной, но мало звучащей. Почему «Тобол» и почему «много званых»? Это первая тайна, которую придется раскрыть самому читателю. Фактически в названии Иванов предлагает формулу места, короткое выражение главной особенности территории. Тобол физико-географический объект, много званых - его социальная характеристика.

Почему же много званых? Тобол, если говорить о долине реки, - не самый оживленный исторический ареал, не перенаселенный, не центральный в какой-либо хозяйственной структуре. Тобол - протяженная река, на берегах которой не так много городов, наибольшие среди них сегодня Курган, Кустанай и Тобольск. Если понимать под Тоболом территорию всего речного бассейна, то это и Южное, и Среднее, и даже Северное Зауралье с крупными городами: Екатеринбургом, Челябинском, Нижним Тагилом и Тюменью. В этом случае Иванов, наверное, первый, кто так озаглавил социально-экономический регион. Отметим, что бассейн Тобола - главный ареал сосредоточения населения и крупнейших городов в границах современного Уральского федерального округа, но на это в научной литературе и практике территориального управления еще не было сделано акцента.

Название свидетельствует о географическом романе, но имеющем более широкий охват и пространственно-временной, и территориальный. Основной район действия - таежное сибирское Зауралье, бассейны Тобола, Иртыша и Оби, время - начало XVIII в.

Работа писателя выстраивается почти по географическим канонам. Автор применяет разномасштабный взгляд на территорию. От планировки города Тобольска, топографии остяцкого и вогульского поселков до территории всей Сибири и даже Северной и Центральной Евразии. Это называется «игра масштабом» - метод высокой географической культуры. Роман многомаршрутный, а маршруты разномасштабные и разнонаправленные: есть очень длинные и ориентированы по разным сторонам света. Большинство сюжетных поворотов книги, так или иначе, можно считать путевыми. Маршрут по тобольскому меридиану (по реке из Тобольска в Березово) длиной около 1000 км неявно выступает главной сюжетной стезей.

В книге три основные смысловые географические точки: Тобольск - столица Сибири, Певлор остяцкий поселок с долиной Оби ниже Карымкар, Конда - район вогульских поселений. Самые остросюжетные части романа связаны с Тобольском, остяцкими и вогульскими местами, с Тобольским кремлем, рекой и тайгой. Сибирская град-столица, река и лес - географическая ландшафтная триада зарождающегося Зауральского региона России. Кажется, Иванов - певец леса и реки, но мы знаем, что им хорошо подается и степь («Увидеть русский бунт»).

В настоящее время Сибирь - самый большой регион мира, имеющий собственное географическое название. Иванов показывает, что уже в Петровские времена Сибирь представляла собой единый регион в отношении хозяйства, управления, понимания, уклада, внутренних и международных связей. Сибирь была географически идентифицирована еще тогда и, возможно, сильнее, чем сейчас.

Сибирь показана как огромное пространство, где много географии. Карта - это первое дело, средство производства на таком неизведанном пространстве, где всюду белые пятна. Карта - сложное и важнейшее государственное дело. Семен Ремезов в центре событий. Он - ключевая фигура, при этом обожаемая автором, от него вьется сюжет. На нем держится основной смысл романа. Это фигура с самым насыщенным, ярко раскрашенным характером. Ремезов - романтик и прагматик идеальное, судя по роману, сочетание для Сибири. Он патриот, «фанат» Сибири. Иванов раскрывает в нем образ знатока Сибири, естествоиспытателя, первокраеведа. Семья Ремезова показана как пример и эталон интересной уважаемой сибирской семьи.

Глава Сибири губернатор Гагарин - вторая центральная фигура. Если автор явно симпатизирует Ремезову, то Гагарина подает по-разному. Этим Иванов подталкивает читателя к мысли о вспомогательной и вторичной роли административной власти в Сибири, ее продажности, о 
вторичности прагматизма в этом сложном регионе по отношению к романтике и бескорыстному служению своему делу.

Тобольский кремль создается именно из романтических соображений как символ Русской Сибири. Благодаря кремлю ни один из городов Сибири не имеет такой яркой архитектурной доминанты, как Тобольск. В настоящее время Тобольский кремль представляет собой, возможно, главную историкокультурную достопримечательность Азиатской части России. В том числе по этой причине Тобольск признается современной туристской столицей Сибири.

Значение работ писателя велико. Оно связано с представлением Урала и Сибири как территорий очень интересных, выражается в воспитании гордости за свои края, в побуждении к познанию регионов. Следует отметить значительное влияние работ А.В.Иванова на развитие внутреннего туризма и краеведения. Благодаря большому личному опыту он понимает современный мир путешествий. Для туризма важными факторами являются легендирование и продвижение территории - романы Иванова показывают это блестяще.

\section{Библиографический список}

1. Зырянов А.И. Формула места // Региональные исследования. 2013. № 2(40). С. 20-24.

2. Зырянов А.И. Новые подходы к туристскому развитию региона в проекте «Пермь Великая» // География и регион. Т.VI. Туризм. Пермь, 2015. С. 86-90.

3. Иванов А.В. Географ глобус пропил. М.: Редакция Елены Шубиной, 2015. 448 с.

4. Иванов А.В. Сердце Пармы М.: АСТ, 2016. 512 с.

5. Иванов А.В. Тобол. Много званых. Роман-пеплум. М.: Редакция Елены Шубиной, 2017. 704 с.

\section{References}

1. Zyrianov, A.I. (2013), "Location formula", Regional nye issledovanija, no 2(40). pp. 20-24.

2. Zyrianov, A.I. (2015), "New approaches to tourism development of the region in the "Great Perm» project", Geografija i region. T.VI. pp. 86-90.

3. Ivanov, A.V. Geograf globus propil [The Geographer Drank His Globe Away], Redaktsija Eleny Shubinoj, Moscow, Russia.

4. Ivanov, A.V. (2016), Serdtse Parmy, AST, Moscow, Russia.

5. Ivanov, A.V. (2017), Tobol. Mnogo zvanyh, Redaktsija Eleny Shubinoj, Moscow, Russia.

Поступила в редакцию: 25.05.2017

\section{Сведения об авторе}

\section{Зырянов Александр Иванович}

доктор географических наук, заведующий кафедрой туризма, декан географического факультета Пермского государственного национального исследовательского университета; 614990, Россия, г. Пермь, ул. Букирева, 15;
About the author

\section{Aleksandr I. Zyrianov}

Doctor of Geographical Sciences, Head of the Department of Tourism, Dean of the Geography Faculty, Perm State University; 15, Bukireva st., Perm, 614990, Russia;

$$
\text { e-mail: ziryanov@psu.ru }
$$

\section{Просьба ссылаться на эту статью в русскоязычных источниках следующим образом:} Зырянов А.И. Глобус, Парма и Тобол (о писателе Алексее Иванове как географе) // Географический вестник $=$ Geographical bulletin. 2017. №3(42). C.43-47. doi 10.17072/2079-7877-2017-3-43-47

Please cite this article in English as:

Zyrianov A.I. Globus, Parma and Tobol (about the writer Alexei Ivanov as a geographer) // Geographical bulletin. 2017. № 3(42). P. 43-47. doi 10.17072/2079-7877-2017-3-43-47 